Acest articol se citează:

Dumbravă, A. C., (2016/2018). Relația dintre factorii de personalitate Big Five și dependența de gaming. Studia Doctoralia. Psychology and Educational Science, 11-12, 20-38.

\title{
RELAȚIA DINTRE FACTORII DE PERSONALITATE BIG FIVE ȘI DEPENDENȚA DE GAMING
}

Andrei Cosmin Dumbravă, Universitatea din București, Facultatea de Psihologie și Științele Educației. Email: dumbrava.andrei.cosmin@gmail.com

\begin{abstract}
As we can see the significant increase in the number of video games on the market, but also an increase in the number of people who choose to relax in a virtual world at the expense of reality. In this context, present study has the primary objective of discovering whether any of the Big Five personality components can predict gaming addiction. A total of 137 respondents aged between 10 and 55 participated in the data collection. As a result of the data analysis, the neuroticism factor explains $28 \%$ of the gaming addiction variable $(R 2=.28, p<0.01)$ and the introversion factor variance explains $4 \%$ of the gaming addiction variable $(R 2=.04, p<0.05)$. The rest of the personality factors did not correlate significantly with the gaming addiction variable. The types of video games did not moderate the relationship between emotional stability and gaming addiction.
\end{abstract}

Keywords: gaming addiction, Big Five, video games, emotion stability, extraversion.

\section{Introducere}

În ultimii ani, jocurile digitale au devenit o activitate majoră de petrecere a timpului liber mai ales că, odată cu dezvoltarea internetului, a permis oamenilor să participe la jocuri online de tip multiplayer care implică o cooperare și/sau concurență (Herodotou, Winters, \& Kambouri, 2012). Popularitatea jocurilor online și adoptarea lor exponențială în comunitate au ridicat probleme în comunitățile publice si științifice, precum și un număr mare de studii care au fost efectuate pentru a testa impactul pozitiv și negativ asupra vieții de zi cu zi și 
asupra bunăstării psihologice a pasionaților de jocuri video (Billieux și colab., 2015).

Pe de o parte, au fost identificate mai multe rezultate pozitive. De exemplu, s-a arătat ca implicarea în jocuri video online colective promovează dezvoltarea capitalului social online (de exemplu: crearea de noi prietenii, oferirea și primirea de sprijin emoțional prin intermediul comunicării online, socializarea $\mathrm{cu}$ alte persoane provenind din medii sociale și economice diferite, sau promovarea agajamentului civic online) (Billieux și colab., 2015).

Datele preliminare au sugerat, de asemenea, că unele funcții cognitive (atenția, percepția, abilitățile vizuale) pot fi îmbunătățite prin petrecerea timpului liber în compania anumitor genuri de jocuri video ce au la bază acțiunea (Green \& Bavelier, 2008). Mai mult decât atât, alte cercetări au subliniat că o implicare ridicată în jocurile online (reflectată prin poziția din clasament și realizările din joc) nu împiedică buna desfășurare a activităților de zi cu zi și nu dezvolta probleme în cadrul relațiilor sociale (Billieux și colab., 2015). Acest lucru poate duce la ideea că majoritatea pasionaților de jocuri video nu se joacă pentru a-și satiface nevoile psihologice de bază (Herodotou, Kambouri, \& Winters, 2014; Billieux și colab., 2015).

Pe de altă parte, tot mai multe dovezi sugerează că utilizarea jocurilor online poate deveni problematică și poate cauza un impact negativ asupra vieții de zi cu zi (Hussain \& Griffiths, 2009). În 2013, a fost introdus în manualul DSM-V în Secțiunea 3, tulburarea jocurilor pe internet (Internet Gaming Desorder), ce include mai multe criterii prin care se manifestă aceasta tulburare, făcând diferența între această tulburare și tulburarea jocurilor de noroc. Ulterior aceste criterii trecute în DSM-V au fost validate (Ko și colab., 2014; Billieux și colab., 2015).

O problematică studiată în cazul jocurilor video, ar fi însăși dependența, ce a fost cuantificată prin intermediul numărului de ore petrecute în cadrul jocului video și efectele pe care le produce.

Un studiu pilot în acest sens a fost realizat de Hussain \& Griffiths (2009) pentru a studia efectele fiziologice și sociale generate de utilizarea excesivă a jocurilor video online de tip MMORPG (Massively multiplayer online role-playing game). Acest gen a fost ales ca fiind definitoriu pentru populația țintă deoarece s-au estimat în 2006 că sunt 
peste cinci milioane de jucători în lumea întreagă (Chan \& Vorderer, 2006). Printre rezultatele cercetării pilot s-au identificat diferențe între pasionați prin intermediul numărului de ore petrecute pe săptamână. Eșantionul a fost format din 119 participanți 83 bărbați și 32 femei, cu vârste cuprinse între 18 și 69 de ani, din 3 țări diferite (SUA, Canada și UK). Cei care se jucau excesiv, adică cei care petreceau mai mult de 35h/săptămână în compania jocurilor de tip MMORPG, au însumat o medie $40.4 \mathrm{~h} /$ săptămână față de cei care erau utlizatori obișnuiți ce au adunat în medie 11.1h/ săptămână. Un lucru interesant descoperit în acest studiu pilot a fost faptul ca $39 \%$ din participanţii de gen masculin și $9 \%$ din participanții de gen feminin au susținut că petrec mai mult timp decât își propun în compania jocurilor online. Un procent de 53\% dintre participanți au raportat că nu se joacă pentru a putea scăpa de problemele cotidiene, dar 1 din 3 participanți au raportat că folosesc acest timp în compania jocurilor pentru a-și schimba dispoziția.

O altă diferență semnificativă descoperită între jucătorii de World of Warcraft (WOW) și cei care nu îl jucau, în ceea ce privește tipul alocat jocului pe săptămână a fost de $17 \mathrm{~h} /$ săptămână vs $4 \mathrm{~h} /$ săptămână. Însă jucătorii de WOW au obținut un scor la viteza de reacție la stimul mai mare față de cei ce nu se jucau. Un alt plus al jucătorilor a fost că pot discrimina mult mai bine țintele ce apar pe ecran în timpul sesiunii de joc și au obținut un scor mai mare la variabila dezinhibiție ce măsoară capacitatea de a răspunde la stimul în general. O limitare a acestui studiu ar fi numărul de participanți la acest studiu, fiind indentificat un număr mic raportat la populația de jucători ai acestui joc. Din aceste motive autorii își asumă faptul că rezultatele studiului nu pot fi generalizate deoarece eșantionul nu este reprezentativ. În schimb autorii dau ca direcții viitoare idei de cercetare asupra efectelor pe care timpul efectiv petrecut în compania jocurilor ar putea genera rezultate academice mai slabe și o creștere a consumului de substanțe (Decker \& Gay, 2011).

În cadrul populației jucătorilor de WOW, s-a mai descoperit o diferență interesantă între cei care sunt dependenți de acest joc și cei care doar s-au implicat în joc. O diferență raportată la numărul de ore petrecute în fața jocului ar fi de 30h/ săptămână pentru cei dependenți și 20h/săptămână pentru cei care s-au implicat. Nu a existat o diferență 
semnificativă între participanții de gen masculin și feminin raportat la numărul de ore petrecute în jocul World of Warcraft (25.5h/ săptămână vs $25.1 \mathrm{~h} /$ săptămână). Cei 577 de participanții au mai fost rugați să completeze două chestionare: unul ce măsoară calitatea vieții în 4 factori (sănatatea fizică, sănatatea psihologică, relațiile sociale și mediul înconjurător) și un chestionar ce măsura tendința de implicare în activități. S-a identificat o diferență semnificativă în perceperea calității vieții între jucătorii implicați și cei dependeți. Cei implicați au avut scoruri mult mai bune asupra factorilor ce sunt asociați cu calitatea vieții decât cei dependeți. O diferență semnificativă a fost indentificată și in cazul scorurilor chestionarului ce măsoară tendința de implicare, cei dependeți au avut o medie a scorurilor mai mare decât cei care se implică. Un lucru interesant asupra calității vieții la jucătorii de nivel înalt de WOW este faptul că $66.7 \%$ dintre aceștia o percep ca fiind una bună și foarte bună, iar numai $6 \%$ din ei o percep ca fiind nesatisfăcătoare sau puțin satisfăcatoare (Lehenbauer-Baum \& Fohringer, 2015).

\section{Personalitatea Big Five și dependența de gaming}

În cercetările pe tema dependenților de jocuri video s-a folosit chestionarele Big Five. Braun, Stopfer, Müller, Beutel, \& Egloff (2016) fac diferența dintre diferite tipuri de jucători și dintre diferite genuri de jocuri prin intermediul acestui chestionar de personalitate. La acest studiu au participat 2891 de oameni, cu vârste cuprinse între 13 și 65 de ani. S-a descoperit că utilizarea jocurilor video au corelat pozitiv cu nevrotismul și negativ cu extraversia și conștiinciozitatea. Relațiile dintre ultilizarea jocurilor video și deschiderea spre experiențe ori agreabilitatea au dispărut după ce variabila gen a fost controlată. Comparând tipurile de jucători, cei care nu se jucau aveau scoruri mari pe nevrotism, dar scorurile lor nu erau diferite semnificativ de scorurile jucătorilor dependenți. Jucătorii obișnuiți au avut scoruri mai mici la nevrotism față de cei care nu se jucau și jucatorii dependenți. Jucătorii dependenți au avut scoruri mici la extraversie, față de cei care nu se joacă și jucătorii medii. Deschiderea spre experiențe, a relaționat cu variabila gen, astfel barbații care nu se joacă au avut scoruri mai mari pe deschidere, decât jucătorii medii. Pe când femeile care se joacă au avut 
un scor semnificativ mai mare pe deschidere spre experiențe, decât cele care nu se joacă. $\mathrm{Nu}$ există diferențe între tipurile de jucători asupra variabilei agreabilitate. În ceea ce privește conștiinciozitatea, cele mai mari scoruri le-au avut cei care nu se joacă, urmați de jucătorii medii, apoi de jucătorii dependenți. În ceea ce privește genurile jocurilor, participanții care au preferat jocurile de acțiune au avut scoruri mai mici la nevrotism decât cei care au ales jocurile de tip simulator sau RP (roleplaying). Participanții care au ales genul acțiune, au avut cel mai mare scor la variabila extraversie. Cel mai mare scor la deschidere spre experiențe, 1 -au avut cei care au preferat genul RP, dar diferențele dintre genuri la această variabilă nu erau seminificative. Femeile care au preferat jocurile de tip RP au avut un scor mai mare la deschidere spre experiențe, decât femeile care au preferat jocurile de tip strategie. Participanții care au preferat alte genuri de jocuri nu au avut un scor semnificativ la variabila agreabilitate. Participanții care au preferat jocurile de tip simulator, au avut cel mai mare scor la nivelul de conștiinciozitate.

Graham \& Gosling (2013) spun că pasionații de jocuri video se implică în jocuri de tip MMORPG având o varietate de motive în spatele alegerii. De exemplu, unii jucători vor alege aceste jocuri deoarece important pentru ei este partea de socializare implicată în timpul jocului, ceilalți joacă pentru că aduce un sentiment de realizare o dată cu diverse activități desfășurate cu succes în joc. Studiile precedente au arătat că aceste motive sunt asociate cu diferențele individuale precum genul, numărul de ani în care aceștia s-au jucat jocuri online. Personalitatea este cunoscută ca fiind asociată cu comportamentele din timpul jocului, crescând posibilitatea să existe o legătură între personalitate și motivele pentru care aleg să se joace. Așa că, acest sudiu examina relația dintre trăsăturile de personalitate, studiate cu Big Five, ale pasionaților de jocuri video și motivele acestora pentru care jucau World of Warcraft. Rezultatele au arătat că există câteva legături între personalitatea jucătorului și motivația pentru a se juca. De exemplu, indivizii ce joacă, deoarece partea de socializare este implicată, tind să obțină rezultate mari la extraversie, agreabilitate, nevrotism și deschidere spre experiență, în timp ce cei care joacă pentru ca sentimentul de realizare să fie activat, tind să obțină scoruri ridicate pe 
extraversie și nevrotism, dar obțin scoruri mici pe agreabilitate și conștiinciozitate.

Lehenbauer-Baum \& Fohringer (2015) au realizat studiul pentru descoperirea diferențelor dintre jucătorii dependenți și jucătorii implicați. Au participat 577 de subiecți, din țări vorbitoare de limbă germană din Europa (Germania, Austria și Elveția), jucători de nivel înalt în jocul World of Warcraft, cu vârste cuprinse între 18 și 64 de ani. În urma procedurilor statistice s-au descoperit diferențe seminificative la nivelul factorilor Big Five deschidere spre experiență și conștiinciozitate. Jucătorii dependenți au avut scoruri mai mari la deschidere spre experiență și conștiinciozitate față de jucătorii implicați.

Landers \& Lounsbury (2006) au încercat să explice relația dintre utilizarea internetului și Big Five, folosind 117 studenți în calitate de participanți la studiu. Rezultatele au arătat că, utilizarea ridicată a internetului a corelat negativ cu trei dintre factorii de personalitate Big Five (Agreabilitate, Conștiinciozitate și Extraversie). Asta explică faptul că niveluri mai mici de agreabilitate, conștiinciozitate și extraversie se asociază cu timp mai ridicat de utilizare a internetului.

Pe baza evidențelor din literatură, considerăm că:

H1: Factorul Big Five extraversie prezice dependența de gaming.

H2: Factorul Big Five agreabilitate prezice dependența de gaming.

H3: Factorul Big Five conștiinciozitate prezice dependența de gaming.

H4: Factorul Big Five stabilitate emoțională prezice dependența de gaming.

H5: Factorul Big Five deschidere spre experiență prezice dependența de gaming.

\section{Tipurile de jocuri în explicarea conceptului de dependență}

O variabilă considerată importantă în explicarea conceptului de dependență de jocuri video a fost și genurile jocurilor. Genurile de jocuri video sunt definite ca fiind o clasificare a interacțiunii dintre poveste, efecte vizuale și tacticile programate în jocuri. Fiecare gen de joc oferă informații viitorului jucător despre elementele definitorii ale jocului. De altfel studiile derulate au avut ca scop descoperirea legăturii dintre genul de joc și dependența de jocuri video.

Stetina, Kothgassner, Lehenbauer, \& Kryspin-Exner (2011) au realizat o cercetare ce avea ca obiectiv examinarea problematicii 
comportamentului jucătorilor și al tendințelor depresive ce puteau fi determinate de diferite genuri online de jocuri. La acest studiu au participat 468 de subiecți din țările vorbitoare de limbă germană din Europa (Germania, Austria și Elveția), cu vârste cuprinse între 11 și 67 de ani. Acest eșantion a fost împărțit în funcție de preferințele pentru genurile jocurilor online MMORPG (massively multiplayer online role playing games), OES (online-ego-shooters), RTS (real time strategy). Rezultatele au arătat că la niciun participant nu s-au identificat comportamente problematice și nici tendințe depresive. Se pare totuși că pasionații de jocuri de tip MMORPG ar avea un nivel mai mic al stimei de sine față de cei care preferă genul OES, dar nu au fost diferențe seminficative între cei ce preferă genul MMORPG și RTS. Aceste rezultate demonstrează ca pasionații de MMORPG preferă acest tip de joc pentru componenta socială pe care o găsesc, unde pot crea relații de prietenie, participă într-o comunitate pentru a ascunde problema reală a nivelului stimei de sine scăzut în lumea reală (Ceyhan \& Ceyhan, 2008; Kim \& Davis, 2009). Jucătorii de MMORPG au obținut scoruri mai mari decât ceilalți ce preferă RTS sau OES la variabila evadare. Prin aceasta se explică faptul că cei ce preferă genul MMORPG se joacă pentru a fugi de lumea reală și de problemele cu care se confruntă. Ceea ce totuși a remarcat acest studiu este că se pot dezvolta probleme de ordin comportamental sau probleme depresive dacă se petrec des mai mult de 8 ore pe sesiunea de joc.

Rehbein, Staudt, Hanslmaier, \& Kliem (2016) au desfășurat o cercetare în Germania, ce a avut ca scop să explice dacă numărul de ore petrecute în cadrul unui joc video poate poate fi influențat în funcție de genul din care face parte jocul. Astfel s-a încercat o înțelegere mai amănunțită a rolului mediator ce poate fi adus de genurile de jocuri, în relația dintre gen și numărul de ore jucate. În urma analizei răspunsurilor celor 3073 de participanți la studiu, cu vârste cuprinse între 16-93 de ani, s-au putut descoperi faptul că participanții de gen masculin se joacă mai multe ore pe zi decât participanții de gen feminin. La o vârstă mai înaintată și în funcție de tipul de job la care este angajat un individ (full-time sau part-time) timpul alocat zilnic jocurilor video scade, în plus indivizii ce au absolvit o formă de învățământ superior se joacă zilnic mai puțin decât cei care au un nivel educațional mai scăzut. 
Totuși, rezultatele statistice au relevat faptul că jocurile din genurile role-playing $(\mathrm{RP})$, shooter și simulator prezic un timp mai mare alocat zilnic jocurilor. Un alt lucru interesant este faptul că genul de joc ales este prezis de genul indivizilor, adică indivizii de gen masculin preferă genul RP, shooter, sportiv, curse, acțiune-aventură și strategie pe când participanţii de gen feminin preferă mai degrabă jocurile logice. Ultimul rezultat al acestui studiu prezintă relația de mediere pe care o are genul de joc în relația dintre genul pasionatului și timpul alocat. Această relație de mediere relevă că bărbații preferă jocurile din genul RP și shooter și aceasta duce la un timp mai mare petrecut în lumea virtuală.

Manero, Torrente, Freire, \& Fernandez-Manjon (2016) au realizat un studiu, pe o populație din Spania unde au dorit să afle cum obiceiurile și preferințele în materie de gaming pot afecta comportamentul. Pentru a putea explica acest lucru, cei 754 de participanți au fost împărtiți în 4 grupuri, în urma răspunsurilor date la testul GPQ (Game Preferences Questionnaire). Aceste grupuri au fost contituite pentru a putea analiza tipurile de jucători și preferințele lor în materie de jocuri video. Primul grup era reprezentat de pasionații de jocuri video care joacă orice tip de joc, cu o frecvență mare, al doilea grup reprezentat de pasionații de jocuri video hardcore, care preferă să joace doar jocuri de tip first person shooter (FPS), aventură și jocurile sportive, al treilea grup era reprezentat de jucătorii ocazionali, care preferă jocurile de tip musical, jocuri de gândire și jocuri sociale, iar ultimul grup ce este reprezentat de cei care nu se joacă, cei care de obicei nu această preferință.

Așadar, considerând că genurile de joc influențează dependența de gaming, în mod specific, propun următoarea ipoteză:

H6: Genurile de jocuri moderează relația dintre stabilitate emoțională și dependența de gaming. 


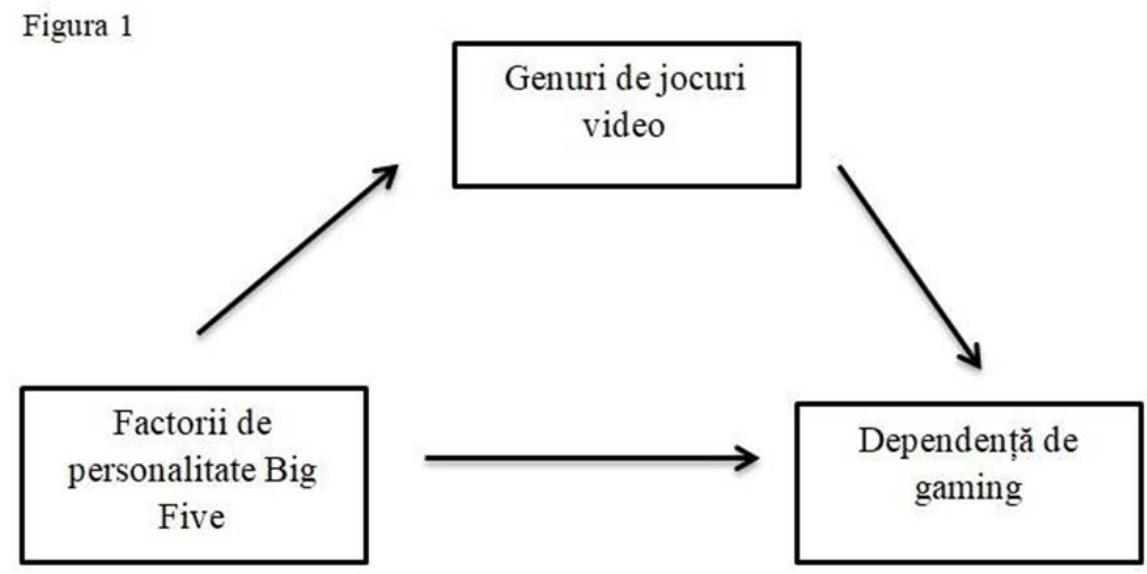

\section{Metodă}

\section{Participanți și procedură}

La acest studiu au participat 137 de respondenți cu vârste între 10 și 55 de ani. Deoarece chestionarul pentru dependența de gaming a fost validat doar pe populație adolescentă cu vârste între 12 și 18 ani, au fost excluși 30 de respondenți din eșantion. Participanții sunt adolescenți de naționalitate română, 94 de gen masculin $(87.9 \%)$ și 13 de gen feminin (12.1\%), cu vârste cuprinse între 14 și 18 ani $(M=15.95, S D=1.34)$.

Chestionarele în format digital au fost distribuite prin intermediul rețelelor sociale pe 2 grupuri ce erau destinate pasionațiilor de jocuri video și pe alte 3 grupuri de liceu din România.

\section{Instrumente}

Personalitate Big Five

Chestionarul de personalitate Big Five se bazează pe modelul factorial al personalității dezvoltat de McCrae și Costa (1987). În România acest chestionar a fost adaptat de Iliescu, Popa, \& Dimache (2015). În cadrul cercetării desfășurate pentru adaptarea formei scurte a factorilor Big Five pe populație românească, factorul extraversie a obținut un coeficient Cronbach Alfa de .82, factorul agreabilitate .78, 
factorul conștiinciozitate .74, factorul stabilitate emoțională .84 și factorul deschidere spre experiență .78.

În cadrul acestei lucrări s-a folosit forma scurtă a factorilor Big Five format din 10 itemi pentru fiecare factor cu scală Likert cu 5 puncte 1 fiind dezacord total, iar 5 fiind acord total. Un exemplu de item ar fi: „Sunt sufletul petrecerii" sau „Imi place ordinea". În cadrul acestei cercetări factorii Big Five au obținut următorii coeficienții Cronbach Alfa: factorul extraversie .85 , factorul agreabilitate .87 , factorul conștiinciozitate .81 , factorul stabilitate emoțională .83 și factorul deschidere spre experiență .80 .

Dependența de gaming

Chestionarul pentru dependența de gaming este creat conform criteriilor descrise în DSM. Chestionarul este compus din 21 de itemi, cu scală Likert cu 5 puncte 1 fiind niciodată, iar 5 fiind foarte des. Subiecții erau nevoiți să raspundă la întrebări raportându-se la cât de des, în ultimele 6 luni, s-au întâmplat situațiile descrise. Un exemplu de întrebare ar fi: „Te-ai simțit dependent de un joc?" sau "Ai mințit în legătură cu timpul pe care îl aloci jocurilor?". În urma analizelor s-a validat acest test și a obținut un scor Cronbach Alfa de .94 (Lemmens, Valkenburg, \& Peter, 2009). În cadrul acest chestionar a obținut un scor Cronbach Alfa de .88 .

Genurile de jocuri video

Genurile de jocuri video sunt definite ca fiind o clasificare a interacțiunii dintre poveste, efecte vizuale și tacticile programate în jocuri. $\mathrm{Nu}$ există o clasificare exactă a jocurilor de aceea în cercetările științifice s-au folosit ori genul jocului (precum genul acțiune, strategie) ori subgenuri (precum MMORPG, shooter) (Stetina și colab., 2011; Hellström, Nilsson, Leppert, \& Åslund, 2012; Rehbein și colab., 2016; Manero și colab., 2016; Braun și colab., 2016).

În această cercetare au fost aleasă clasificarea generală a genurilor de jocuri în funcție de elementele dominante din joc (poveste, tactici, efecte vizuale etc.). Astfel, genurile alese sunt: acțiune, acțiune-aventură, aventură, strategie, role-playing, simulator și sport (Apperley T., 2006). 


\section{Rezultate}

O primă privire asupra relațiilor dintre variabila independentă factorii de personalitate și variabila dependentă dependența de gaming este afișată în Tabelul 1. După cum se poate vedea doar doi din cei cinci factori au corelat cu scorurile variabilei dependență de gaming.

Factorul stabilitate emoțională $(\mathrm{M}=30.98, \mathrm{SD}=8.21)$ a corelat negativ cu varibila dependență de gaming $(\mathrm{M}=58.24, \mathrm{SD}=14.79)$. Acest rezultat se traduce în faptul că un nivel ridicat de nevrotism se asociază cu un nivel ridicat al dependenței de gaming și invers. Mărimea efectului pentru acest coeficient de corelație $\left(r^{2}=.28\right)$ este unul mic și exprimă faptul că doar $28 \%$ din varianță este comună celor două variabile.

Factorul extraversie $(\mathrm{M}=30.89, \mathrm{SD}=8.10)$ a corelat negativ $(\mathrm{r}=-.2$; $\mathrm{p}<0.05) \mathrm{cu}$ variabila dependență de gaming $(\mathrm{M}=58.24, \mathrm{SD}=14.79)$. Acest rezultat se traduce în faptul că un nivel scăzut de extraversie se ascociază cu un nivel ridicat al dependenței de gaming și invers. Mărimea efectului pentru acest coeficient de corelație $\left(r^{2}=.04\right)$ este una foarte mică și exprimă faptul că doar $4 \%$ din varianță este comună celor două variabile.

Ceilalți factori de personalitate Big Five agreabilitate $(\mathrm{M}=36.25, \mathrm{SD}$ $=7.78)$, conștiinciozitate $(\mathrm{M}=32.60, \mathrm{SD}=7.47)$ și deschidere spre experiență $(\mathrm{M}=37.88, \mathrm{SD}=6.22) \mathrm{nu}$ au corelat semnificativ statistic cu variabila dependență de gaming $(\mathrm{M}=58.24, \mathrm{SD}=14.79)$.

Tabel 1. Statistici descriptive, coeficienții alpha și coeficienții de corelație

\begin{tabular}{lcccccc}
\hline & \multicolumn{3}{c}{ Statistici Descriptive } & \multicolumn{2}{c}{$\begin{array}{c}\text { Dependență } \\
\text { de gaming }\end{array}$} \\
\multicolumn{1}{c}{ Variabile } & $\mathrm{M}$ & $\mathrm{SD}$ & Alpha & $\mathrm{r}$ & $\mathrm{r}^{2}$ \\
\hline 1. Extraversie & 30.89 & 8.10 & .85 & $-.21^{*}$ & .04 \\
2. Agreabilitate & 36.25 & 7.78 & .87 & -0.9 & .81
\end{tabular}




\begin{tabular}{|c|c|c|c|c|}
\hline 3. Conștiinciozitate & 32.60 & 7.47 & .81 & -.13 \\
\hline 4. Stabilitate Emoțională & 30.98 & 8.21 & .83 & $-.53^{* *}$ \\
\hline 5.Deschidere spreexperință & 37.88 & 6.22 & .80 & -.11 \\
\hline 6. Dependență de gaming & 58.24 & 14.79 & .88 & \\
\hline
\end{tabular}

Notă. ${ }^{*} \mathrm{p}<0.05 ;{ }^{* *} \mathrm{p}<0.01 ; \mathrm{N}=107$

Tabel 2. Analiza de regresie între factorii Big Five și Dependența de Gaming

\begin{tabular}{lccc}
\hline & \multicolumn{3}{c}{ Dependenț̆ de gaming } \\
\hline \multicolumn{1}{c}{ Variabile independente } & $\beta$ & $\mathrm{R}^{2}$ & $\mathrm{~F}$ \\
\hline 1. Extraversie & $-.21^{*}$ & .048 & 5.25 \\
2. Agreabilitate & -.09 & .009 & 0.99 \\
3. Conștiinciozitate & -.13 & .017 & 1.85 \\
4. Stabilitate Emoțională & $-.53^{* *}$ & .289 & 42.70 \\
5. Deschidere spre experință & -.11 & .014 & 1.47 \\
& & & \\
\hline
\end{tabular}

Notă. B= Beta Standardizat; ${ }^{*} \mathrm{p}<0.05 ;{ }^{* *} \mathrm{p}<0.01 ; \mathrm{N}=107$

Pentru a putea testa ipotezele în care fiecare factor de personalitate prezice dependența de jocuri video, s-a realizat analiza de regresie unde s-au introdus fiecare factor Big Five ca variabilă independentă și variabila dependentă dependența de gaming. Rezultatele se pot vedea în Tabelul 2.

În urma analizei de regresie varianța factorul stabilitate emotională explică în proporție de $28 \%$ varianța variabilei dependență de gaming $\left(\mathrm{R}^{2}=.28, \mathrm{p}<0.01\right)$. 
A doua relație semnificativă statistic este între factorul extraversie și dependența de gaming $\left(\mathrm{R}^{2}=.04, \mathrm{p}<0.05\right)$.

Restul factorilor de personalitate agreabilitate, conștiinciozitate și deschidere spre experiență nu au obținut scoruri semnificative statistic în urma analizei de regresie, ceea ce se poate spune că ipotezele H2, H3 și H5 nu sunt susținute de datele analizate.

Pentru a testa ipoteza H6 conform căreia genurile de jocuri ar modera relația dintre factorul de personalitate Big Five stabilitate emoțională și variabila dependența de gaming, s-a realizat analiza în cadrul programului PROCESS. Programul a calculat separat aportul fiecărui predictor posibil și al interacțiunii dintre aceștia asupra variabilei dependente care este dependența de gaming. În plus, programul a standardizat automat variabilele incluse în analiză pentru a evita efectul de multicoloniaritate dintre predictori și efectul interacțiunii acestora (Howitt \& Cramer, 2011, p. 472).

$\mathrm{Au}$ fost alese doar 3 genuri de jocuri care au avut frecvența cea mai mare în urma colectării de date: genul acțiune, genul acțiune-aventură și genul strategie. Rezultatele analizei realizate în PROCESS (Tabel 3) arată că modelul primei analize de moderare unde variabilă moderatoare este genul acțiune este susținut $(\mathrm{F}(3,102)=17.27, \mathrm{p}<0.001$, $\left.\mathrm{R}^{2}=.29\right)$, efectul variabilele predictori asupra dependenței de gaming nu este seminficativ $(\beta=.10, t=.35, p=.72)$.

Modelul celei de-a doua analize de moderare unde variabilă moderatoare este genul acțiune-aventură este susținut $(F(3,102)=20.49$, $\left.\mathrm{p}<0.001, \mathrm{R}^{2}=.29\right)$, efectul variabilele predictori asupra dependenței de gaming nu este seminficativ $(\beta=.15, \mathrm{t}=.54, \mathrm{p}=.58)$.

Ultimul model al analizei de moderare unde variabilă moderatoare este genul strategie este susținut $\left(\mathrm{F}(3,102)=18.27, \mathrm{p}<0.001, \mathrm{R}^{2}=.31\right)$, efectul variabilele predictori asupra dependenței de gaming nu este seminficativ $(\beta=-.10, \mathrm{t}=.35, \mathrm{p}=.72)$. Astfel se poate spune că ipoteza H6 nu se confirmă și putem zice că genurile de jocuri nu moderează relația dintre stabilitate emoțională și dependența de gaming. 
Tabel 3. Analize de moderare cu genurile de jocuri ca moderatori ai relației dintre stabilitate Emoțională și dependența degaming

\begin{tabular}{|c|c|c|c|c|c|}
\hline Ipoteză & $\begin{array}{l}\text { Predict } \\
\text { ori }\end{array}$ & $\beta$ & $\mathrm{T}$ & $\begin{array}{c}\Delta \mathrm{R}^{2} \\
\left(\text { change in } \mathrm{R}^{2}\right) \\
\text { datorat interacțiunii }\end{array}$ & $\begin{array}{c}F \\
\text { pentru } \\
\Delta \mathrm{R}^{2}\end{array}$ \\
\hline \multirow[t]{4}{*}{ H6 } & Stabilitate Emoțională & -.96 & $-6.90^{* *}$ & & \\
\hline & Genul Acțiune & 3.00 & 1.15 & & \\
\hline & Stabilitate Emoțională* Genul Acțiune & .10 & .35 & .00 & 3.31 \\
\hline & Model $\mathrm{R}^{2}$ & .29 & & & \\
\hline \multirow[t]{4}{*}{ H6 } & Stabilitate Emoțională & -.95 & $-6.53^{* *}$ & & \\
\hline & Genul Acțiune Aventură & 2.77 & 1.11 & & \\
\hline & $\begin{array}{l}\text { Stabilitate Emoțională Genul Acțiune } \\
\text { Aventură }\end{array}$ & .15 & .54 & .00 & .29 \\
\hline & Model $\mathrm{R}^{2}$ & .29 & & & \\
\hline \multirow[t]{4}{*}{ H6 } & Stabilitate Emoțională & -1.03 & $-7.25^{* *}$ & & \\
\hline & Genul Stategie & -4.72 & -1.87 & & \\
\hline & Stabilitate Emoțională* Genul Stategie & -.10 & -.35 & .00 & .12 \\
\hline & Model $\mathrm{R}^{2}$ & .31 & & & \\
\hline
\end{tabular}

Notă. ${ }^{*} \mathrm{p}<.05 ;{ }^{* *} \mathrm{p}<.01$. 


\section{Discuții}

Această cercetare a avut ca temă o problemă care începe să devină destul de importantă odată cu dezvoltarea tehnologiei. Jucatul pe calculator, consolă sau telefon a devenit o activitate relaxantă, dar pentru alți pasionați jocurile video sunt un mediu propice pentru socializare sau pentru a te întrece cu alții.

Obectivul principal al acestui studiu a fost să se descopere dacă vreuna din componentele personalității Big Five poate prezice dependența de gaming. Rezultatele au adus un aport semnificativ pentru cercetarea în domeniu, chiar dacă numai câteva din ipoteze s-au confirmat. Acestea nu sunt conforme cu rezultatele obținute de Braun și colab. (2016), singurul rezultat asemănător ar fi doar că extraversia a corelat negativ cu dependența de gaming.

Am evaluat ce factori de personalitate explică dependența de gaming. Din rezultate a reieșit că adolescenții pasionați de jocuri video ce trăiesc stări de anxietate dese, au de multe ori izbucniri nervoase și nu au un control bun al impulsurilor emoționale pot dezvolta un comportament dependent ce generează probleme psihosociale cu familia, prietenii. Această dependență poate duce la o evadare a problemelor zilnice prin intermediul jocurilor video. De altfel, adolescenții pasionați de jocuri video care sunt introverți, inactivi, retrași, timizi, tăcuți pot dezvolta comportament dependent. Acest lucru orientează preferința jucătorilor spre socializarea în mediul online decât în viața reală (Lemmens, Valkenburg, \& Peter, 2011; Kowert, Vogelgesang, Festl, \& Quandt, 2015).

Ceilalți factori nu au putut explica în vreun fel comportamentul dependent. Din rezultate se pare că adolescenții care sunt egoiști, lipsiți de toleranță sau cei care sunt cordiali, prietenoși, altruiști nu sunt generatoare de comportament dependent de gaming. Cei care respectă regulile, preferă ordinea sau cei care au interes scăzut pentru ordine și reguli, care evită responsabilitățile nu au explicat comportamentul adictiv de jocuri video. Nici adolescenții care sunt caracterizați ca fiind nonconformiști, originali în atitudine și creativi, interesați de activități culturale sau cei care dau dovadă de puțină originalitate și creativitate, dezinteresați de activități culturale nu dezvoltă un comportament 
problematic generat de jocurile video. Cercetările în acest sens nu au arătat că vreunul din acești factori: agreabilitate, conștiinciozitate sau deschidere spre experiență este asociat cu dependența de gaming. Probabil există alte variabile sau fațete ale personalității care ar putea explica cu succes ce caracteristici de personalitate sunt generatoare de comportament dependent de jocuri video.

Am evaluat influența genurilor jocurilor video asupra relației dintre stabilitate emoțională și dependența de gaming, se pare că acestea nu influențează nici prin diminuarea, nici prin amplificarea relației dintre variabila independentă și cea dependentă.

Un plus adus în cercetarea acestei probleme, poate chiar un punct de plecare pentru viitoare studii, este investigarea relației dintre factorii de personalitate Big Five și dependența de gaming. Faptul că stabilitatea emoțională prezice dependența de gaming în proporție de $28 \%$, am putea spune psihologic că indivizii care au stări de anxietate, sunt neliniștiți pot devolta o dependență de jocurile video dacă această activitate este una obișnuită. Pe lângă stabilitatea emoțională și extraversia a obținut un scor semnificativ în predicția dependeței de gaming, $4 \%$.

Însă, consider că, eșantionul este destul de mic pentru a putea extrapola rezultatele la nivel de populație. Un alt plus ar fi faptul că această cercetare a avut ca populație adolescenții din România și faptul că s-a încercat să se descopere dacă diferitele genuri de jocuri aduc o influență în această problematică a dependenței de gaming.

\section{Limite și direcții viitoare}

O primă limitare a acestui studiu ar fi faptul că eșantionul format în urma colectării datelor este destul de mic raportat la populația de adolescenți care preferă să se joace jocuri video.

$\mathrm{O}$ a doua limitare ar fi că instrumentul pentru măsurarea dependenței de gaming nu a fost validat pe o populație românească și că traducerea acestui chestionar nu a fost făcută de oameni specializați, fapt care ar putea afecta validitatea chestionarului. În plus, populația de adolescenți cu vârste cuprinse între 12-18 ani, în care s-a validat instrumentul să fie o problemă deoarece ar putea exclude participanți adulți cu vârste peste 18 ani, ce ar fi dorit să aducă increment. 
O ultimă limitare ar fi itemul pentru colectarea datelor despre identificarea genurilor din care au făcut parte jocurile jucate de participanți în ultimele 6 luni, a fost cu alegere multiplă. Practic aceștia identificau genurile din care făceau parte toate jocurile jucate de aceștia în ultimile 6 luni, ceea ce a dus doar la alegerea primelor 3 genuri cu frecvența cea mai mare. Probabil dacă subiecții alegeau genul din care făcea parte jocul jucat cel mai des în ultimele 6 luni ar fi putut oferi alte rezultate la analiza de moderare.

Ca direcții viitoare pot încuraja în replicarea acestui studiu, eventual cu utilizarea unui alt chestionar pentru dependența de gaming validat și pe populație adultă. De dorit ar fi ca, în urma colectării datelor, să fie un eșantion reprezentativ mai mare pentru ca rezultatele să poată fi extrapolate la nivel de populație. Poate pe viitor se va putea studia efectul la nivel social al dependeței de jocuri video în relație $\mathrm{cu}$ personalitatea. Este nevoie de o privire de ansamblu a eventualelor efecte psihosociale pe care le poate genera o astfel de problematică.

\section{Bibliografie}

Apperley, T. H. (2006). Genre and game studies. Simulation $\mathcal{E}$ Gaming, $37,6-23$.

Billieux, J., Thorens, G., Khazaal, Y., Zullino, D., Achab, S., \& Van der Linden, M. (2015). Problematic involvement in online games: A cluster analytic approach. Computers in Human Behavior, 43, 242-250.

Braun, B., Stopfer, J. M., Müller, K. W., Beutel, M. E., \& Egloff, B. (2016). Personality and video gaming: Comparing regular gamers, nongamers, and gaming addicts and differentiating between game genres. Computers in Human Behavior, 55, 406-412.

Ceyhan, A. A., \& Ceyhan, E. (2008). Loneliness, depression, and computer self efficacy as predictors of problematic internet use. CyberPsychology and Behavior, 11, 699-701.

Chan, E., \& Vorderer, P. (2006). Massively multiplayer online games. În P. Vorderer \& J. Bryant (Eds.) Playing video games: Motives, 
responses, and consequences (pp. 77- 90). Mahwah: Lawrence Erlbaum Associates.

Decker, S. A., \& Gay, J. N. (2011). Cognitive-bias toward gaming-related words and disinhibition in World of Warcraft gamers. Computers in Human Behavior, 27, 798- 810.

Graham, L., \& Gosling, S. D. (2013). Personality Profiles Associated with Different Motivationsfor Playing World of Warcraft. CyberPsychology, Behavior and Social Networking, 16, 189-193.

Green, C. S., \& Bavelier, D. (2008). Exercising your brain: A review of human brain plasticity and training-induced learning. Psychology and Aging, 23, 692-701.

Hellström, C., Nilsson, K. W., Leppert, J., \& Åslund, C. (2012). Influences of motives to play and time spent gaming on the negative consequences of adolescent online computer gaming. Computers in Human Behavior, 28, 1379-1387.

Herodotou, C., Kambouri, M., \& Winters, N. (2014). Dispelling the myth of the socioemotionally dissatisfied gamer. Computers in Human Behavior, 32, 23-31.

Herodotou, C., Winters, N., \& Kambouri, M. (2012). A Motivationally Oriented Approach to Understanding Game Appropriation. International Journal of Human-Computer Interaction, 28(1), 3447.

Howitt, D., \& Cramer, D.(2011). The influence of moderator variables on relationships between two variables. În D. Howitt \& D. Cramer, Introduction to statistics in psychology (pp. 465-485). Pearson Education

Hussain, Z., \& Griffiths, M. D. (2009). Excessive use of massively multiplayer online role-playing games: A pilot study. International Journal of Mental Health and Addiction, 7, 563-571.

Iliescu, D., Popa, M., \& Dimache, R. (2015). Adaptarea românească a Setului Internaţional de Itemi de Personalitate: IPIP-Ro Psihologia Resurselor Umane, 13, 83- 112.

Kim, H. K., \& Davis, K. E. (2009). Towards a comprehensive theory of problematic internet use: Evaluating the role of self-esteem, anxiety, flow and the self-rated importance of internet activities. Computers in Human Behavior, 25, 490-500. 
Ko, C. H., Yen, J. Y., Chen, S. H., Wang, P. V., Chen, C. S., \& Yen, C. F. (2014). Evaluation of the diagnostic criteria for Internet gaming disorder in the DSM-5 among young adults in Taiwan. Journal of Psychiatric Research, 53, 103-110.

Kowert, R., Vogelgesang, J., Festl, R., \& Quandt, T. (2015). Psychosocial causes and consequences of online video game play. Computers in Human Behavior, 45, 51-58.

Landers, R. N., \& J.W., L. (2006). An investigation of Big Five and narrow personality traits in relation to Internet usage. Computers in Human Behavior, 22, 283-293.

Lehenbauer-Baum, M., \& Fohringer, M. (2015). Towards classification criteria for internet gaming disorder: Debunking differences between addiction and high engagement in a German sample of World of Warcraft players. Computers in Human Behavior, 45, 345-351.

Lemmens, J. S., Valkenburg, P. M., \& Peter, J. (2009). Development and Validation of a Game Addiction Scale for Adolescents. Media Psychology, 12, 77-95.

Manero, B., Torrente, J., Freire, M., \& Fernandez-Manjon, B. (2016). An instrument to build a gamer clustering framework according to gaming preferences and habits. Computers in Human Behavior, 62, 353-363.

McCrae, R. R., \& Costa, P. T. (1987). Validation of the five-factor model of personality across instruments and observers. Journal of Personality and Social Psychology, 52, 81- 90

Rehbein, F., Staudt, A., Hanslmaier, M., \& Kliem, S. (2016). Video game playing in the general adult population of Germany: Can higher gaming time of males be explained by gender specific genre preferences? Computers in Human Behavior, 55, 729-735.

Stetina, B. U., Kothgassner, O. D., Lehenbauer, M., \& Kryspin-Exner, I. (2011). Beyond the fascination of online-games: Probing addictive behavior and depression in the world of onlinegaming. Computers in Human Behavior, 27, 473-479. 